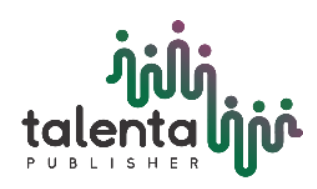

Jurnal Teknik Kimia USU

Vol. 09, No. 1, Maret 2020 |34-40

ISSN : 2337-4888

Homepage: https://talenta.usu.ac.id/jtk

\title{
Bakteri Indigen Pendegradasi Hidrokarbon Minyak Bumi di Kabupaten Siak Provinsi Riau
}

\author{
Indigenous Bacteria for Degrading Petroleum Hydrocarbons \\ in Siak Regency Riau Province
}

\author{
Riryn Novianty*, Saryono, Amir Awaluddin, Nova Wahyu Pratiwi \\ Program Studi S1 Kimia FMIPA, Universitas Riau \\ Kampus Bina Widya Km 12,5 Simpang Baru Pekanbaru 28293 Indonesia \\ *Email : rirynnovianty@ lecturer.unri.ac.id
}

\begin{abstract}
Abstrak
Proses produksi, pengilangan dan transportasi minyak bumi dapat menyebabkan polutan yang berbahaya bagi lingkungan serta makhluk hidup yang berada di sekitarnya. Mikroorganisme indigen dapat menjadi solusi dalam menguraikan hidrokarbon yang sulit didegradasi. Penelitian ini bertujuan untuk mengisolasi bakteri indigen dari tanah yang terkontaminasi zat polutan dan menguji efektifitasnya dalam mendegradasi hidrokarbon. Penelitian ini diawali dengan pengambilan sampel tanah di Badan Operasi Bersama PT Siak Bumi Pusako-Pertamina Hulu Kabupaten Siak Provinsi Riau dengan metoda purposive sampling. Langkah selanjutnya adalah isolasi bakteri indigen, menguji parameter $\mathrm{pH}$, Optical density (OD) dan kadar $\mathrm{CO}_{2}$ selama 16 hari masa inkubasi dan menentukan persentase biodegradasi tertinggi. Hasil menunjukkan bahwa Pseudomonas sp. dengan kode BTM2 (Bakteri Tanah Minyak 2) memiliki persentase terbesar $(52,20 \%)$ setelah 16 hari inkubasi dibawah kondisi optimum dalam mendegradasi total hidrokarbon minyak bumi. Pseudomonas sp. BTM2 adalah isolat yang paling efektif dalam mendegradasi hidrokarbon.
\end{abstract}

Kata Kunci : biodegradasi, hidrokarbon, Pseudomonas sp

\begin{abstract}
The process of producing, refining and transporting petroleum can cause pollutants that are harmful to the environment and the living things that surround them. Indigenous microorganisms can be a solution to degrade hydrocarbons that are difficult to degrade. This study aims to isolate the indigenous bacteria from pollutant-contaminated soil and test its effectiveness in degrading hydrocarbons. The research began with soil sampling at the Joint Operating Agency of PT Siak Bumi Pusako-Pertamina Hulu Siak Regency, Riau Province with a purposive sampling method. The next step is the isolation of indigenous bacteria, testing the parameters of $\mathrm{pH}$, Optical density (OD) and $\mathrm{CO}_{2}$ levels during the 16 incubation periods and determining the highest percentage of biodegradation. The results showed that Pseudomonas sp. with a code BTM2 (Bakteri Tanah Minyak 2) had the largest percentage $(52.20 \%)$ after 16 days of incubation under optimum conditions to degrade the total hydrocarbon of petroleum. Pseudomonas sp. BTM2 is the most effective isolate to degrade hydrocarbons.
\end{abstract}

Keywords: biodegradation, hydrocarbon, Pseudomonas $s p$ 


\section{Pendahuluan}

Minyak bumi merupakan pilar utama bagi kehidupan manusia yang memiliki dampak penting bagi lingkungan. Negara produsen minyak bumi terbesar di dunia adalah Amerika Serikat, Arab Saudi, Rusia, Kanada, dan China. Produsen minyak bumi peringkat ke-24 adalah Indonesia dengan produksi sebanyak 824.000 barrel per hari [1]. Provinsi Riau termasuk daerah penghasil minyak bumi terbesar di Indonesia.

Berbagai kecelakaan di laut yang menyebabkan tumpahan minyak masif pernah terjadi di Showa Maru Selat Malaka (1975), Exxon Valdez di Alasca (1989), Amoco Cadiz di Selat Inggris (1978) dan blow up di sumur minyak Macondo milik British Petroleum (BP) di Teluk Meksiko (2010). Kasus Minyak Montara yang terjadi di Laut Timor juga berakibat pada wilayah perairan Indonesia khususnya di wilayah Provinsi Nusa Tenggara Timur. Hanya saja, PTTEP Australasia, berdasarkan partnership research dengan beberapa perguruan tinggi di Australia, menyatakan bahwa dampak dari Kasus Minyak Montara tidak menimbulkan dampak negatif ke wilayah perairan Indonesia [2].

Bioremediasi merupakan teknik yang aman untuk mengatasi permasalahan polutan minyak bumi. Penggunaan mikroba menjadi pilihan karena hidrokarbon dapat dimanfaatkan sebagai sumber karbon untuk menghasilkan energi [3]. Mikroba yang dapat digunakan salah satunya yakni mikroba indigen yang merupakan biota lokal berasal dari lingkungan yang tercemar. Studi tentang biodegradasi hidrokarbon memanfaatkan bakteri indigen telah banyak dilakukan salah satunya di India menggunakan Pseudomonas aeruginosa [4]. Bakteri indigen memiliki kemampuan mendegradasi senyawa hidrokarbon untuk keperluan metabolismenya dan sudah teradaptasi dengan berbagai faktor lingkungan di habitat asalnya. Enzim yang diproduksi oleh bakteri tersebut akan mengkatalisa penguraian substrat menjadi produk yang lebih sederhana [5].

Permasalahan di sekitar Badan Operasi Bersama PT Siak Bumi Pusako-Pertamina Hulu Kabupaten Siak Provinsi Riau diharapkan dapat diatasi dengan menggunakan bakteri indigen dari tanah tercemar yang berada di wilayah tersebut. Hasil biodegradasi senyawa toksik naftalena menggunakan bakteri indigen Pseudomonas sp telah diperoleh dengan persentase sebesar 37,69\% [6]. Potensi jamur Aspergillus sp dalam mendegradasi hidrokarbon dan senyawa toksik naftalena juga telah diperoleh dengan persentase masing-masing sebesar $61,00 \%$ [7] dan 55,13\% [8].

\section{Teori}

Minyak bumi mengandung campuran kompleks hidrokarbon padat, cair dan gas yang merupakan hasil akhir penguraian bahan-bahan hewani dan nabati yang telah terpendam dalam kerak bumi dalam waktu lama karna adanya tekanan dan panas, residu organik ini berkonversi menjadi minyak bumi. Kemudian minyak bumi berpindah ke atas menuju permukaan bumi atau terperangkap dalam reservoir [9]. Minyak bumi merupakan campuran komplek sejumlah hidrokarbon dan sedikit non-hidrokarbon seperti nitrogen dan belerang [10]. Minyak bumi yang dihasilkan di Indonesia bervariasi jenisnya dari ringan encer yang berwarna kecoklatan dan mengandung bagian-bagian ringan yang mudah disuling sampai pada jenis kental yang merupakan substansi setengah padat berwarna kehitaman dengan sedikit mengandung bagian ringan [11].

Biodegradasi merupakan suatu proses yang penting bagi rehabilitasi lingkungan yang tercemar minyak bumi ataupun produk-produknya, dengan memanfaatkan aktivitas mikroorganisme untuk menguraikan pencemar tersebut menjadi bentuk yang lebih sederhana, tidak berbahaya dan memberikan nilai tambah bagi lingkungan [12]. Biodegradasi dapat dilakukan dengan dua pendekatan, pertama dengan memanfaatkan mikroorganisme alamiah setempat untuk merombak polutan dengan cara memperbaiki kondisi pertumbuhan mikroorganisme yang bersangkutan. Pendekatan kedua merupakan inokulasi ke daerah terkontaminasi, menggunakan inokulum mikroorganisme perombak polutan yang telah diisolasi dan dibiakkan di laboratorium [13].

Mikroorganisme yang banyak hidup dan berperan di lingkungan hidrokarbon minyak bumi sebagian besar adalah bakteri. Bakteri yang sesuai harus mempunyai kemampuan fisiologi dan metabolik untuk mendegradasi bahan pencemar [14]. Bakteri mampu beradaptasi pada lingkungan hidrokarbon melalui beberapa cara, yaitu:

1. Pembentukan bagian hidrofobik pada dinding sel sehingga meningkatkan afinitas sel terhadap hidrokarbon.

2. Dihasilkannya surfaktan ektraselular yang dapat meningkatkan kelarutan hidrokarbon.

3. Modifikasi intraselular membran sitoplasmik yang dapat mengurangi toksisitas hidrokarbon terhadap bakteri. 
Mekanisme degradasi hidrokarbon alifatik (n-alkana) secara aerob dan anaerob dapat dilihat pada Gambar 1.

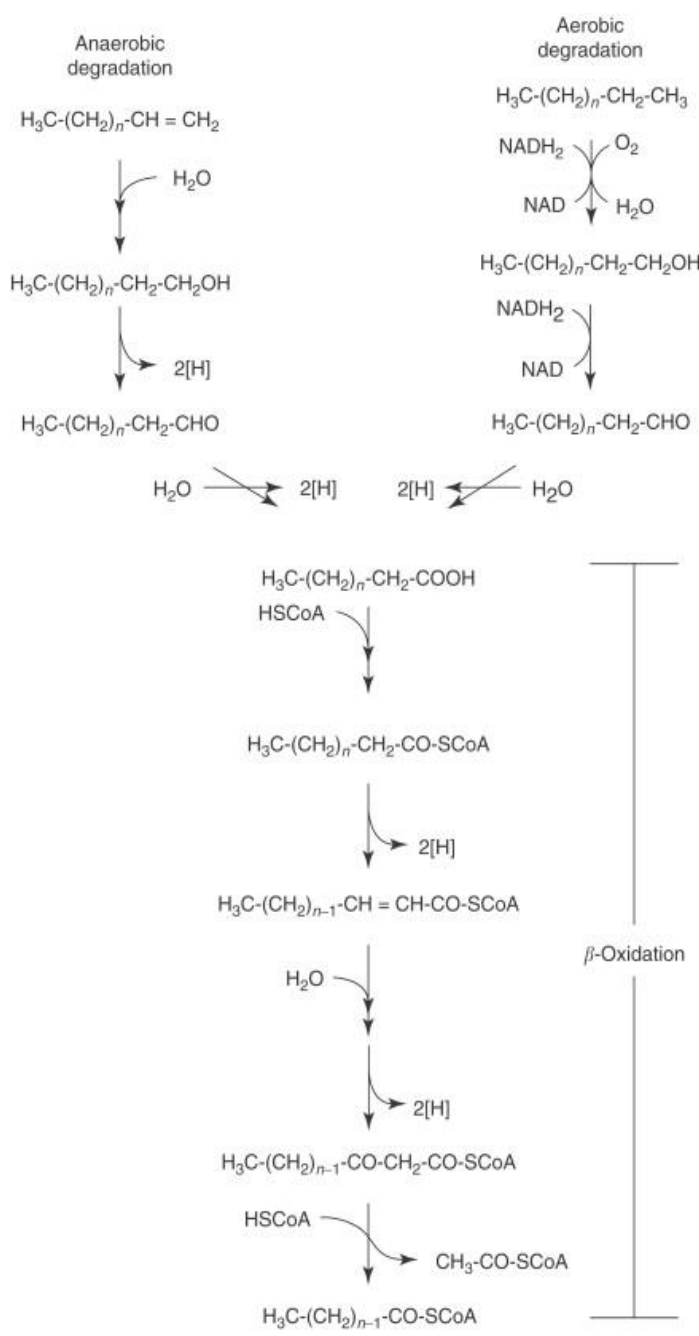

Gambar 1. Mekanisme biodegradasi n-alkana

\section{Metodologi Penelitian \\ Persiapan sampel}

Sampel diperoleh dari tanah Badan Operasi Bersama PT Siak Bumi Pusako-Pertamina Hulu Kabupaten Siak Provinsi Riau dengan metoda purposive sampling. Media NA (Nutrient Agar) digunakan untuk kultivasi bakteri.

Kemampuan bakteri sebagai agen biodegradator crude oil ditentukan dengan menggunakan Medium Bushnell Haas yang mengandung crude oil 5\% (v/v) [15]. Bushnell Haas tanpa penambahan crude oil dipersiapkan sebagai kontrol. Kemampuan biodegradasi bakteri terhadap crude oil diukur dengan parameter $\mathrm{pH}$, Optical density (OD) dan kadar $\mathrm{CO}_{2}$ terlarut.

\section{Analisis Minyak Terdegradasi}

Analisis secara gravimetri dilakukan untuk menentukan kadar minyak terdegradasi. $\mathrm{HCl} 1 \%$ ditambahkan untuk menghentikan aktivitas bakteri setelah 16 hari inkubasi. Proses ekstraksi dilakukan menggunakan pelarut n-heksan $10 \%$. Campuran kemudian dikocok pada corong pisah selama 30 menit, lalu didiamkan sampai n-heksana terpisah. Lapisan air dibuang, lapisan n-heksan ditampung dalam labu rotary evaporator $50 \mathrm{ml}$ yang sudah diketahui bobotnya. Kelembaban dihilangkan dengan penambahan natrium sulfat pada ekstrak minyak lalu diuapkan pada suhu $60^{\circ} \mathrm{C}$ sampai n-heksan habis. Berat lapisan minyak yang tertinggal ditimbang dan dihitung kadarnya. Rumus persentase biodegradasi minyak adalah :

$$
\% B=\frac{B M o-B M n}{B M 0} x 100 \ldots \text { (1) }
$$

Keterangan:

$$
\begin{array}{ll}
\% \mathrm{~B} & =\text { Persen Biodegradasi, } \\
\mathrm{BM}_{0} & =\text { Berat Minyak Awal }(\mathrm{g}) \\
\mathrm{BMn} & =\text { Berat Minyak Akhir }(\mathrm{g})
\end{array}
$$

\section{Hasil dan Pembahasan}

Diperoleh enam isolat dari hasil isolasi dengan kode BTM1, BTM2, BTM3, BTM4, BTM5 dan BTM 6 ( BTM = Bakteri Tanah Minyak). Pertumbuhan isolat bakteri dalam medium Bushnel Haas dapat dilihat pada Gambar 2. Karakteristik morfologi hasil identifikasi makroskopis dan mikroskopis dapat dilihat pada Tabel 1.

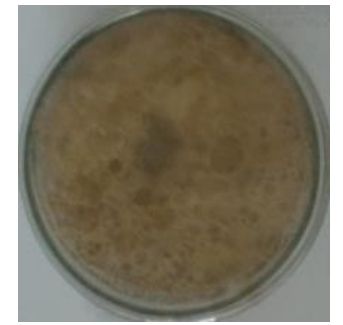

(a)

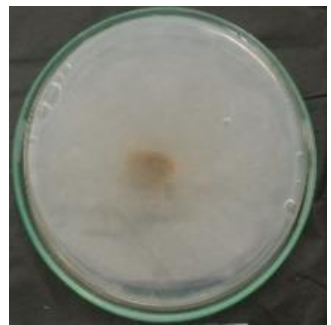

(b)
Gambar 2. Pertumbuhan isolat bakteri (a) pada Bushnell Haas kontrol tanpa crude oil (b) BTM1 pada Bushnell Haas dengan crude oil

Pada Bushnell Haas kontrol tampak bahwa crude oil masih menutupi seluruh permukaan medium sedangkan pada isolat BTM1 sudah banyak berkurang yang menandakan crude oil sudah terdegradasi. Hasil identifikasi menunjukkan bahwa umumnya isolat merupakan bakteri Gram negatif. Parameter pH selama degradasi dapat dilihat pada Gambar 3. 
Tabel 1 . Morfologi koloni isolat

\begin{tabular}{|c|c|c|c|c|c|}
\hline \multirow{2}{*}{ Kode Isolat } & \multicolumn{5}{|c|}{ Morfologi Koloni } \\
\cline { 2 - 6 } & $\begin{array}{c}\text { Bentuk } \\
\text { Tepian }\end{array}$ & $\begin{array}{c}\text { Elevasi } \\
\text { Koloni }\end{array}$ & $\begin{array}{c}\text { Warna } \\
\text { Koloni }\end{array}$ & Bentuk & $\begin{array}{c}\text { Pewarnaan } \\
\text { Gram }\end{array}$ \\
\hline BTM1 & Licin & Cembung & Kuning & Koma & Positif \\
\hline BTM2 & Licin & Datar & Krem & Batang & Negatif \\
\hline BTM3 & Licin & Datar & Krem & Batang & Positif \\
\hline BTM4 & Bergerigi & Datar & Krem & Batang & Negatif \\
\hline BTM5 & Licin & Cembung & Oren & Bulat & Negatif \\
\hline BTM6 & Licin & Cembung & Putih & Batang & Negatif \\
\hline
\end{tabular}

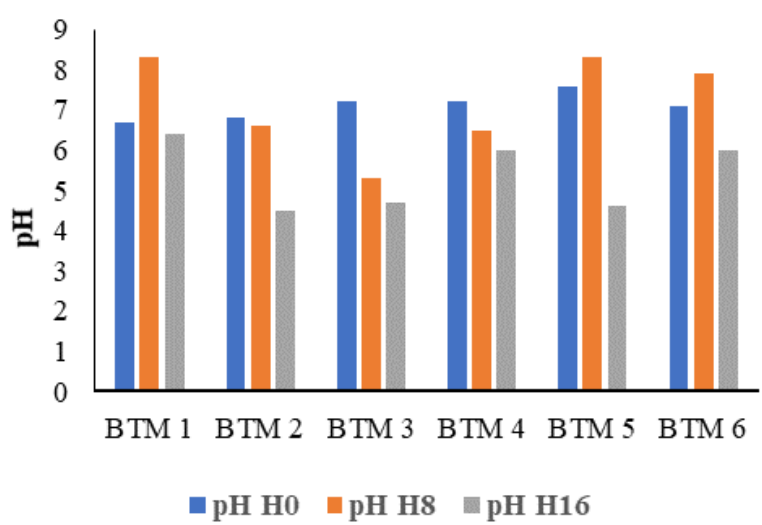

Gambar 3. Parameter pH selama degradasi hidrokarbon

Kenaikan $\mathrm{pH}$ di hari ke-8 inkubasi terjadi pada isolat BTM1, BTM5 dan BTM6. Unsur non hidrokarbon seperti oksigen, sulfur, nitrogen, dan logam-logam juga terkandung dalam minyak bumi. Nitrogen dapat terurai membentuk ammonium karbonat kemudian menjadi amoniak, karbon dioksida dan air. pH media akan naik jika amoniak bereaksi dengan air menjadi amonium hidroksida. Reaksi kimia pada substrat hidrokarbon oleh enzim mono oksigenase akan menyebabkan penurunan $\mathrm{pH}$ selama proses inkubasi dan $\mathrm{pH}$ optimum berada di sekitar 6-8 saat terjadinya proses biodegradasi [16].

Pengukuran nilai Optical Density (OD) menggunakan spektrofotometer dilakukan untuk menentukan jumlah sel bakteri (Gambar 4). Pada awal proses degradasi terjadi kenaikan OD yang menunjukkan bakteri berada dalam fase eksponensial. Biomassa sel akan mencapai jumlah maksimum pada fase stasioner. Selanjutnya jumlah nutrien akan berkurang akibat kompetisi bakteri untuk mendapatkan nutrisi sehingga menyebabkan beberapa sel mati dan yang lainnya tetap tumbuh. Dalam proses biodegradasi hidrokarbon, bakteri akan lebih mudah menguraikan fraksi sederhana berupa hidrokarbon alifatik dibandingkan dengan senyawa Polisiklik Aromatik Hidrokarbon (PAH) yang lebih kompleks [17].

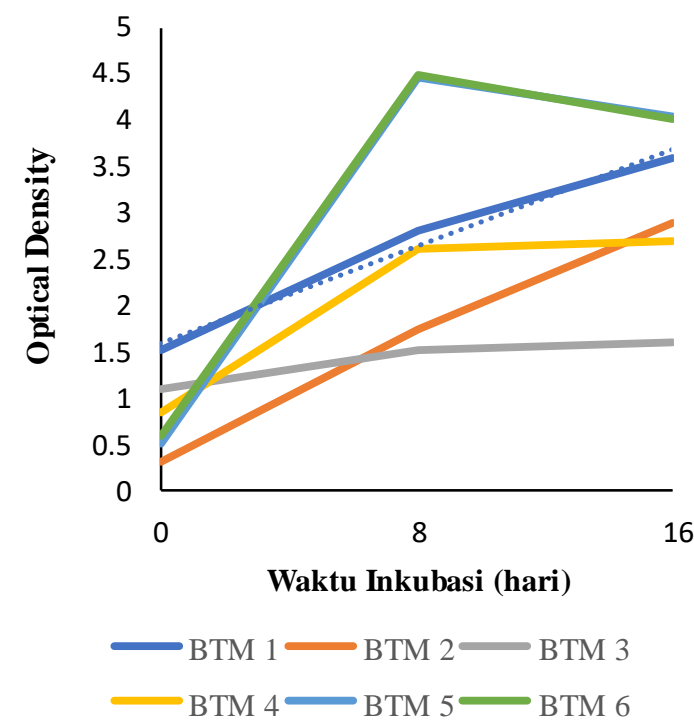

Gambar 4. Parameter OD selama degradasi hidrokarbon

Produk $\mathrm{CO}_{2}$ yang merupakan hasil biodegradasi substrat hidrokarbon dapat dilihat pada Gambar 5. Metabolisme di dalam sel bakteri menghasilkan energi yang sejalan dengan produk sampingnya berupa $\mathrm{CO}_{2}$. Terjadinya penurunan jumlah $\mathrm{CO}_{2}$ disebabkan oleh metabolit toksik yang dihasilkan selama proses biodegradasi [4].

Degradasi paling cepat dan lengkap dari sebagian besar polutan organik disebabkan oleh kondisi aerobic [18]. Serangan intraseluler awal polutan organik adalah proses oksidatif dan aktivasi serta penggabungan oksigen adalah reaksi kuci enzimatik yang dikatalisis oleh oksigenase dan peroksidase. Jalur degradasi perifer mengubah polutan organik selangkah demi selangkah ke zat antara dari metabolisme perantara tengah, 
misalnya, siklus asam tricarboxylic. Biosintesis biomassa sel terjadi dari metabolit prekursor pusat, misalnya, asetil-KoA, suksinat dan piruvat. Gula yang dibutuhkan untuk berbagai biosintesis dan pertumbuhan disintesis oleh gluconeogenesis. Mikroorganisme yang terlibat dalam degradasi minyak didistribusikan secara luas di alam dan telah diisolasi dari tanah dan air dengan potensinya mendegradasi minyak [19]. Mikroba yang mampu memanfaatkan minyak dan produk minyak sebagai satu-satunya sumber karbon dan energi terjadi di udara, air, dan tanah [20]. Diperkirakan bahwa dalam satu gram tanah yang tidak tercemar, hanya ada 100 hingga 1.000 sel mikroorganisme penghancur hidrokarbon, sedangkan, dalam satu gram tanah yang tercemar oleh minyak, jumlahnya meningkat menjadi $1 \times$ $10^{6}$ hingga $5 \times 10^{7} \mathrm{sel}$, terutama jika polusi terjadi berulang kali untuk waktu yang lama [21]. Karakteristik taksonomi dari isolat ini mengidentifikasi mereka sebagai Bacillus sp., Staphylococcus sp., Micrococcus sp., Pseudomonas sp., Psychrobacter sp., dan Alcaligens faecalis [22].

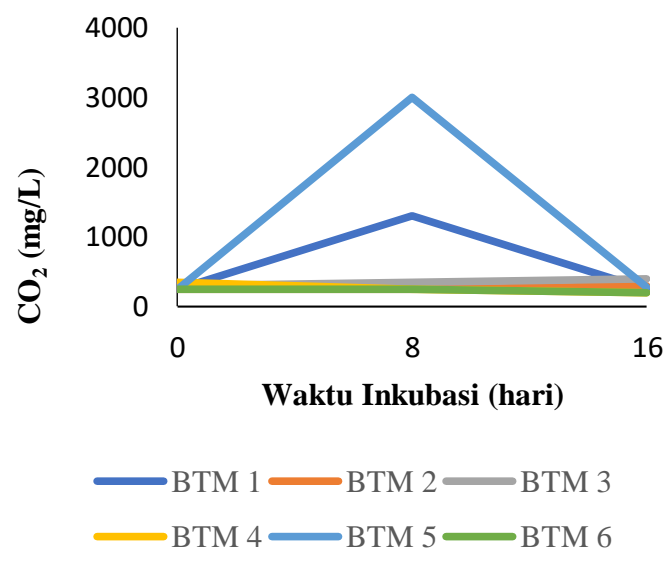

Gambar 5. Parameter $\mathrm{CO}_{2}$ selama degradasi hidrokarbon.

Tingkat biodegradasi minyak mentah di dalam tanah sangat cepat dan mungkin disebabkan oleh mikroorganisme di dalam tanah yang memiliki efisiensi dalam memanfaatkan sisa minyak mentah sebagai sumber karbon dan energi [23]. Minyak mentah mengandung hidrokarbon dan tidak tahan terhadap serangan mikroorganisme. Mikroorganisme yang memanfaatkan hidrokarbon yang diisolasi dari tanah adalah spesies Bacillus, Lactobacter, Arthrobacter, Pseudomonas, Micrococcus, Zoopage, dan Articulosporium. Bacillus sp. mendominasi, terutama di tanah yang tercemar minyak mentah. Ini mungkin karena kemampuan organisme ini untuk menghasilkan spora, yang dapat melindungi mereka dari efek toksik hidrokarbon [24].

Mikroorganisme dianggap sebagai biodegradator yang efisien karena kelimpahannya, keanekaragaman spesies yang luas, dan fleksibilitas katabolik dan anaboliknya, serta kemampuannya untuk beradaptasi dengan kondisi lingkungan yang merugikan. Melalui aktivitas metabolisme mikroorganisme ini, polutan organik dapat diubah menjadi air, $\mathrm{CO}_{2}$ dan biomassa [25]. Degradasi lengkap senyawa ke komponen mineral, di mana karbon organik senyawa dikonversi menjadi $\mathrm{CO}_{2}$ melalui respirasi, disebut mineralisasi. Ketika kondisi aerobik dipertahankan, evolusi $\mathrm{CO}_{2}$ dapat digunakan sebagai ukuran aktivitas metabolisme mikroba dengan akurasi yang masuk akal [26]. Studi yang melibatkan pengukuran laju mineralisasi dapat memberikan informasi penting tentang biodegradabilitas senyawa limbah industri, termasuk residu minyak. Dalam penelitian ini perubahan $\mathrm{pH}, \mathrm{CO}_{2}$ dan pertumbuhan sel secara tidak langsung mengindikasikan degradasi petrol. Persentase biodegradasi hidrokarbon dapat dilihat pada Gambar 6.

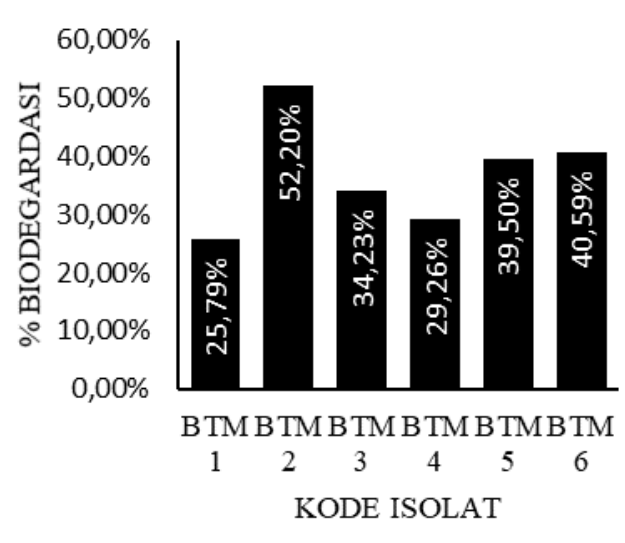

Gambar 6. Persentase biodegradasi hidrokarbon

Dari Gambar 6 terdapat tiga isolat unggul BTM2, BTM5 dan BTM6 dengan nilai persentase biodegradasi berturut-turut sebesar 52,20\%, $39,50 \%$ dan 40,59\%. Hasil identifikasi menunjukkan bahwa isolat tersebut memiliki genus Pseudomonas sp. Hidrokarbon crude oil dapat didegradasi oleh Pseudomonas sp. selama waktu inkubasi 16 hari di bawah kondisi optimum.

\section{Kesimpulan}

Tiga parameter utama untuk menentukan potensi bakteri indigen sebagai agen 
biodegradator adalah $\mathrm{pH}$, OD dan kadar $\mathrm{CO}_{2}$. Pseudomonas sp dengan kode isolat BTM2 dengan persentasi $52,20 \%$ adalah bakteri paling unggul jika dibandingkan dengan isolat lainnya.

\section{Daftar Pustaka}

[1] B. Dudley, "BP Statistical Review of World Energy 2019, no.68," British Petroleum (bp). 2017.

[2] N. P. Suci Meinarni, "Dampak Pencemaran Lingkungan Laut Terjadap Indonesia Akibat Tumpahan Minyak Montara di Laut Timor," J. Komun. Huk., 2016.

[3] B. Gargouri, F. Karray, N. Mhiri, F. Aloui, and S. Sayadi, "Bioremediation of petroleum hydrocarbons-contaminated soil by bacterial consortium isolated from an industrial wastewater treatment plant," J. Chem. Technol. Biotechnol., 2014.

[4] K. V. Darsa and A. J. Thatheyus, "Biodegradation of Petroleum Compound Using Pseudomonas aeruginosa," OALib, vol. 01, no. 05, pp. 1-9, 2014.

[5] A. B. Al-Hawash et al., "Principles of microbial degradation of petroleum hydrocarbons in the environment," Egypt. J. Aquat. Res., vol. 44, no. 2, pp. 71-76, 2018.

[6] R. Novianty, B. Antika, A. Saryono, and N. W. Pratiwi, "Potensi Tiga Isolat Bakteri Indigen dari Kabupaten Siak Provinsi Riau Dalam Mendegradasi Naftalena.”

[7] E. M. Sari, R. Novianty, A. Awaluddin, S. Saryono, and N. W. Pratiwi, "Effectiveness of Crude Oil Degrading Fungi Isolated From Petroleum Hydrocarbon Contaminated Soil In Siak, Riau," Acta Biochim. Indones., vol. 2, no. 1, pp. 15-22, 2019.

[8] R. Novianty, "Biodegradasi Senyawa Toksik Naftalena Pencemar Lingkungan Menggunakan Isolat Fungi Indigen Provinsi Riau," J. Ipteks Terap., vol. 13, no. 3, pp. 165-174, 2020.

[9] U. R. Chaudhuri, Fundamentals of petroleum and petrochemical engineering. Crc Press, 2016.

[10] A. Tiehm and M. Stieber, "Strategies to Improve PAH Bioavailability: Addition of Surfactants, Ozonation and Application of Ultrasound," in Treatment of Contaminated Soil, 2001.

[11] A. Kurniawan, A.J. Effendi, "Biodegradasi Residu Total Petroleum Hidrokarbon di
Bawah Konsentrasi 1\% (W/W) Hasil Proses Bioremediasi," J. Mns. dan Lingkung., vol. 21, no. 3, pp. 286-294, 2015.

[12] Karwati, "Degradasi Hidrokarbon pada Tanah Tercemari Minyak Bumi dengan Isolat A10 dan D8T," in Prosiding Biosains, 2009.

[13] Z. Fanani, B. Yudhono, and V. R. Situmorang, "Degradasi Tanah Lahan Suboptimal oleh Bacillus mycoides Indigenous dan Kinetika Reaksinya," $J$. Lahan Suboptimal J. Suboptimal Lands, vol. 3, no. 1, 2014.

[14] M. Udiharto and P. Pelatihan, "Lokakarya Peranan Bioremediasi dalam Pengelolaan Lingkungan," LIPI, BPPT dan HSF Jerman, Cibinong, pp. 24-39, 1996.

[15] H. Al Nasrawi, "Biodegradation of Crude Oil by Fungi Isolated from Gulf of Mexico," J. Bioremediation Biodegrad., 2012.

[16] C. S. Karigar and S. S. Rao, "Role of microbial enzymes in the bioremediation of pollutants: a review," Enzyme Res., vol. 2011, 2011.

[17] D. Pérez-Pantoja, B. González, and D. H. Pieper, "Aerobic degradation of aromatic hydrocarbons," in Handbook of hydrocarbon and lipid microbiology, 2010.

[18] W. Fritsche and M. Hofrichter, "Aerobic degradation by microorganisms," Biotechnol. New York John Wiley Sons, vol. 11, pp. 146-164, 2000.

[19] M. B. Yakubu, "Biodegradation of Lagoma crude oil using pig dung," African $J$. Biotechnol., 2007.

[20] M. Magot, "Indigenous microbial communities in oil fields," in Petroleum microbiology, American Society of Microbiology, 2005, pp. 21-34.

[21] E. Rosenberg and E. Z. Ron, "Bioremediation of petroleum contamination," Biotechnol. Res. Ser., vol. 6, pp. 100-124, 1996.

[22] M. Pepi, A. Minacci, F. Di Cello, F. Baldi, and R. Fani, "Long-term analysis of diesel fuel consumption in a co-culture of Acinetobacter venetianus, Pseudomonas putida and Alcaligenes faecalis," Antonie Van Leeuwenhoek, vol. 83, no. 1, pp. 3-9, 2003.

[23] S. P. Antai, "Biodegradation of Bonny light crude oil by Bacillus sp and Pseudomonas 
sp," Waste Manag., vol. 10, no. 1, pp. 6164, 1990.

[24] A. K. Onifade and F. A. Abubakar, "Characterization of HydrocarbonDegrading Microorganisms Isolated from Crude Oil Contaminated Soil and Remediation ofthe Soil by Enhanced Natural Attenuation," 2007.

[25] C. B. Boshui, Z. Nan, W. Jiang, W. Jiu, and F. Jianhua, "Biodegradation of petroleum hydrocarbon by Pseudomonas aeruginosa," China Petro Proc Petrochem Technol, vol. 14, pp. 66-70, 2012.

[26] G. Genouw, F. De Naeyer, P. Van Meenen, H. de Werf, W. De Nijs, and W. Verstraete, "Degradation of oil sludge by landfarminga case-study at the Ghent harbour," Biodegradation, vol. 5, no. 1, pp. 37-46, 1994. 